\title{
Analysis of the Influence of Knowledge About Taxes, Motivation to Pay Taxes on Taxpaying Compliance
}

\author{
Sonny, SE., BKP ${ }^{1}$ \\ Muljadi Djaja, SE.Ak, SH, CPA, CA, BKP ${ }^{2}$ \\ Institut STIAMI \\ stellayoung1881@yahoo.com ${ }^{1}$ \\ kkpmuljadi@yahoo.com ${ }^{2}$ \\ DOI: 10.29322/IJSRP.11.07.2021.p11574 \\ http://dx.doi.org/10.29322/IJSRP.11.07.2021.p11574
}

\begin{abstract}
This study aims to determine: the effect of knowledge about taxes, the motivation to pay taxes on the compliance of individual taxpayers at the X Tax Office. Respondents in this study are individual taxpayers who actively come to submit SPT directly at the X Tax Office. using quantitative with a descriptive approach. This study uses three variables, namely the independent variable Knowledge of Taxes and Motivation to Pay Taxes and the dependent variable of Individual Obligatory Compliance. Primary data were collected by distributing questionnaires to 120 respondents using nonprobability sampling with convenience sampling method. This sampling decision was made because existing taxpayers are registered at different tax offices according to the area they live in. Based on the results of the correlation test, it shows that the relationship between the motivation to pay taxes and the compliance of individual taxpayers is 0.625 which is in the medium category based on the existing coefficients, namely $(0.70-0.899)$. The results of this study indicate that knowledge about taxes, motivation to pay taxes has a significant relationship to individual taxpayer compliance, with a significant level of $t$ count is 3.488> than $t$ table 2.861. Showing Ha acceptance and after testing the hypothesis in this study, it can be seen that partially influences the (independent variable) motivation to pay taxes with (the dependent variable) the compliance of individual taxpayers at the Tax Office X.
\end{abstract}

Keywords: Tax, Motivation, Compliance, Taxpayer

\section{INTRODUCTION}

In the current era of globalization, many things will become uncertain. According to Zain, M. (2008) there are two things that make us certain, namely "Taxes" and "Death". There is almost nowhere in the world if everything is tax free, but there are some places that are remote and have no connection to the outside world at all. The company is included in one of the major shareholders with a portion of $30 \%$ before it is distributed to other shareholders, therefore employees who have a salary must receive a discount before they go to spend.

Tax is an obligatory contribution to the state that is owed by an entity or individual which is compelling and based on law, then does not receive direct compensation and uses the state's needs for the greatest prosperity of the people. Taxes are also a part of the life of society and the state, almost many people carry out activities and are dealing with taxes, taxes are also still the prima donna source of state income. A very visible case is the incident in 2010 that there was tax evasion by 100 taxpayers in Indonesia ranging from state-owned companies to private companies which had a value of up to Rp. 51 trillion. Things like this to be used as the level of objectivity of the examiner will all be questioned, between considerations in the political field or in the field of taxation.

Paying taxes can be done in an honest and efficient manner which encourages composing body taxpayers or individual taxpayers. Tax management through tax avoidance. Unlike the tax smuggling (tax evasion), both unilaterally tax evasion and bilateral tax evasion, which have violated the provisions or provisions of taxation legislation. Development of information technology can also increase international transactions to create tax avoidance strategies to increase. Several schemes that all use allied companies in implementing transfer pricing where profits will be shifted to a country that has a lower tax rate than the prevailing tax rate in Indonesia.

One of the innovations that have recently been carried out by the Director General of Taxes which has detected fraud in taxpayers is by launching Circular No.96 / PJ / 2009 on October 5, 2009 regarding the Total Ratio benchmarking as well as guidelines that can be utilized. The Director General of Taxes to develop a pattern that can be used to detect more moderate taxpayer compliance, namely by means of benchmarks. A pattern like this is a very practical testing indicator, a tax officer that detects and analyzes the fairness of the government tax liability of each taxpayer (WP) is the same as a lie detector for a taxpayer. However, in addition to a testing tool for detection, the brenchmark will also be a balancing tool for the implementation of the self-assessment system. Taxpayers who are not in accordance with the benchmark have the meaning that compliance has not been achieved as this should all be carried out in accordance with the mandate of Article 29 of the KUP Law.

The advertisement problem can also be seen in its effect on City X's Regional Original Income (PAD) which is due to the non-compliance of the advertisement organizers in paying the taxes owed. During 2011, City X's PAD from the advertisement tax sector experienced a drastic drop of up to $30 \%$ from the initial target set. Chairman of Commission B DPRD X, M. Machmud said that the advertisement tax target in 2011 was IDR 136,000,000,000 (one hundred and thirty-six billion rupiah), but until the end of 
ISSN 2250-3153

2011 the latest revenue from the billboard tax had only reached around IDR 99,800. 000,000 (ninety-nine billion eight hundred million rupiah) or $72.28 \%$ of the targeted revenue (X Post Online. 2012).

Based on the description above, this study tries to examine the influence of motivation and knowledge of taxpayers in paying local taxes. This research is expected to provide an overview of the taxpayers' motivation and knowledge in the field of taxation, increasing the knowledge and compliance of taxpayers, especially advertisement taxpayers in paying their taxes.

\section{LITERATURE REVIEW}

\section{Factors Affecting the Success of the Official Assessment System}

In order for the official assessment system to succeed as expected, of course there are several factors that influence it and must be considered, both by the tax authorities and by taxpayers. The factors that influence the success of the official assessment system can be classified into two.

The first factor is the motivation of the taxpayer, including the following: (1) Tax awareness of taxpayers, the level of awareness of paying taxes is based on the level of taxpayer compliance based on the high legal awareness in paying taxes. In this case the role of the tax authorities is very meaningful because basically the level of taxpayer compliance is based on a good level of understanding about taxes; (2) Honesty of taxpayers, the factor of honesty in paying taxes is very important because with the self-assessment system the government fully gives the public confidence to determine how much tax must be paid according to the provisions The public is expected to report the true amount of tax obligations without any manipulation; (3) The desire to pay taxes, the desire to pay taxes is basically voluntary obedience in paying taxes, with the premise that awareness in paying taxes must be followed by a high desire to pay taxes.

The second factor is the taxpayer's knowledge. Taxpayer's knowledge is related to the discipline of taxpayers in paying their taxes, because discipline is based on an appropriate level of understanding of the tax laws adopted by a country and the accompanying sanctions. Knowledge is a warning about a specific, universal, method, process, pattern and source structure. Remembering something involves thinking about real conditions. Knowledge is influenced by many things, including formal education factors. A person's knowledge of an object contains two aspects, namely positive and negative aspects. These two aspects will determine a person's attitude, the more positive aspects the more positive towards a certain object (Fidel, 2004).

Knowledge is a variety of symptoms that humans encounter and acquire through the observation of reason. Knowledge arises when a person uses his or her mind to recognize certain objects or events that have never been seen or felt before (Reading World, Definition of Knowledge and Factors Affecting Knowledge). Tax knowledge is knowledge about the concept of general provisions in the field of taxation, the types of tax applicable in Indonesia, starting from the tax subject, tax object, tax rate, calculation of payable tax, recording tax payable, to how to file tax reporting. Knowledge of taxation is not only a conceptual understanding based on the Taxation Law, Minister of Finance Decree, Circular, Decree but also the ability or capacity demands.

technical skills how to calculate the amount of tax owed (Supriyati, 2009). High knowledge and insight in the taxpayer has an impact on the higher level of taxpayer compliance (Supriyati and Nur Hidayah, 2007). The attitude of taxpayers towards regional development, the attitude of taxpayers regarding PBB fines, the attitude of taxpayers towards taxpayer services, as well as the attitude of taxpayers that PBB avoidance is common, has been shown to have a significant effect on taxpayer compliance in Semarang (Sulud Kahono, 2003).

\section{Advertising Tax Collection System in Surabaya}

According to the explanation section of the Surabaya City Regional Regulation Number 4 of 2011 concerning Regional Taxes, it explains that the advertisement tax rates that must be paid are in accordance with the size, height, and location of the advertisements installed. Judging from the way in which the amount of advertisement tax is determined, the tax authorities (tax officials) determine / calculate the amount of advertisement tax to be paid. This shows that the billboard tax collection system in Surabaya is using the official assessment system. The criteria for the official assessment system are as follows: (1) The authority to determine the amount of tax owed lies with the tax authorities; (2) Taxpayers are passive in nature; (3) Taxes payable arise after the issuance of a tax assessment letter by the tax authorities (Taxation, 2009).

\section{Motivation Theory}

Motivation to Pay Taxes According to GHONI, H. A. A., 2012. Taxpayer motivation is the driving force that exists on taxpayers externally and internally to carry out their tax obligations starting from registering themselves to paying their payable taxes. Attribution theory explains that a person's motivation in fulfilling tax obligations is determined by external factors that come from outside the individual and internal factors that come from within the individual. Motivation is an abstract concept, to be able to measure its influence on behavior is done by predicting (infrred) and manipulating the symptoms (manipulated) related to behavior. Motivation that encourages taxpayer compliance in meeting the intensity of taxpayers in filling and submitting Tax Returns (SPT) to the Tax Service Office. The number of tax returns submitted to the Tax Office has an impact on the rupiah value of the collected funds and the number of taxpayers who are netted. Thus, taxpayer compliance which is influenced by the motivation to pay taxes can be measured based on the rupiah amount of funds collected and the number of taxpayers who are netted from the taxation sector.

Motivation comes from the Latin word "movere" which means impulse or driving force. This motivation is only given to humans, especially to subordinates or followers (Hasibuan, 2005: 92). According to Luthans, motivation consists of three elements, namely the need (need), drive (drive), and goals (goals). Motivation, this term is sometimes used interchangeably with other terms, such as need, want, drive, or impulse (Andre, 2010).

Basically all humans have basic needs. He shows it in 5 levels which are in the shape of a pyramid, people start pushing from the lowest level. The five levels of need are known as Maslow's Hierarchy of Needs, starting from basic biological needs to more 
complex psychological motives that will only matter after basic needs are met. The need for a rank must be met at least partially before the need for the next rank becomes an important determinant of action.

According to Suyanto, S., \& Putri, IS, 2017 motivation can be divided into two, namely, intrinsic motivation is a motive that becomes active or its function does not need to be stimulated from the outside, and extrinsic motivation is a motive that becomes active because there are external stimuli. Motivation is a force - the forces that exist and work, both in the individual and outside the individual so that the individual understands his situation to direct and drive his behavior to pay his taxes to meet the needs in this case the underlying needs of a person to act and contribute to the State on the goal of achieving the goal. The existence of motivation in terms of paying taxes will affect whether or not individual taxpayers are compliant in carrying out their tax obligations. The higher the motivation of individual taxpayers in paying taxes, the higher the level of compliance, so that tax revenue by the DGT also increases Putri (2016). The results of this study are the basis for the presumption that the motivation to pay taxes has an effect on individual taxpayer compliance.

\section{Motivational Characteristics}

The first characteristic of motivation is quality motivation, which is an impetus that arises from within a person to own and improve the quality of himself and his abilities in the field he is engaged in so that he can carry out his duties properly and correctly. The manifestation of this quality motivation appears in certain professions. If someone wants to become a tax consultant, he must have sufficient knowledge in the field of taxation. The second motivational characteristic is career motivation. Career choice is an expression of a person. Career can be defined as a series of attitudes and behaviors related to a person's work journey throughout his work life. Higher education has a major influence on one's career development.

The third motivational characteristic is economic motivation. Financial rewards consist of direct and indirect awards. Direct rewards can be in the form of payment of the income received, while indirect awards include insurance, sickness benefits, and other programs.

The fourth motivation characteristic is achievement motivation, which is the driving force that motivates a person's work spirit. The need for this achievement will encourage someone to develop creativity and direct all the abilities and energies they have in order to achieve optimal work performance.

The fifth motivation characteristic is learning motivation, which is an internal process that activates, guides, and maintains behavior over time. Individuals are motivated for many different reasons, with different intensities. The existence of this learning motivation will make someone always seek and add knowledge and insight into something new.

The Motivation to Pay Taxes is the potential power that is in the taxpayer which is the background for a taxpayer to pay taxes. This motivation can arise from within and outside the individual. Motivation to Pay Taxes of a taxpayer who comes from outside the taxpayer is the encouragement of tax officials, work environment, friends or relatives who encourage him to pay taxes. Identification of the indicators of the Motivation to Pay Taxes of a taxpayer according to Husen Abdul Ghoni (2012), namely as follows:

1. Intrinsic Motivation

a) Taxpayer's honesty is related to the self-assessment system which requires a high level of honesty from each taxpayer so that the objectives of taxation can be achieved.

b) Taxpayer awareness, the level of awareness will affect the level of one's compliance, the higher the level of awareness of a taxpayer in fulfilling his tax obligations, the higher the level of compliance, and vice versa.

c) The desire to pay taxes, compliance will arise if the awareness in paying taxes is followed by a high desire or willingness of each taxpayer to pay taxes.

2. Extrinsic Motivation

a. Encouragement from the tax apparatus, socialization from the tax apparatus is needed so that individuals know and understand the use of taxes for state development

b. The work environment, friends or relatives, social interactions between individuals encourage someone to take actions that are considered right by the group (the majority), if the individual is alive in the tax-compliant group, he will also be motivated to comply with taxes, and vice versa.

Motivation is what makes an individual behave. If the motivation of the taxpayer is high in fulfilling their tax obligations, development in Indonesia will run according to the predetermined plan, but if the motivation of the community is low, development will be hampered.

\section{The Effect of Motivation to Pay Taxes on Individual Taxpayer Compliance}

Motivation is an impulse that comes from within and outside the individual, which motivates someone to do something activities. The existence of motivation in terms of paying taxes will affect the compliance or failure of individual taxpayers in carrying out their tax obligations. The higher the motivation of individual taxpayers in paying taxes, the higher the level of compliance, so that tax revenue by the DGT will also increase. This is the basis for the assumption that the Motivation to Pay Taxes affects Individual Taxpayer Compliance.

\section{Taxpayer Compliance}

The definition of obedient in the Indonesian dictionary is like to obey, obey (to orders, rules); disciplined. Meanwhile, obedience has a definition of obedience, obedience. Thus, compliance is the motivation of a person, group, or organization to act or not act according to predetermined rules. According to Fuadi, AO, \& Mangoting, Y., 2013. there are several criteria for Compliant Taxpayers, including: a. On time in submitting Annual Tax Returns in the last 3 (three) years. B. In the last year, the submission of periodic tax returns is not more than 3 (three) tax periods for each type of tax and not consecutive c. as referred to above has been submitted not later than the deadline for Submission of the next tax return. There is no tax arrears for all types of taxes as of 
ISSN 2250-3153

December 31, the year prior to determination as a Compliant Taxpayer, excluding tax payable that has not yet matured e. punishment for committing a criminal offense in the field of taxation in ja the last 5 (five) years. Financial reports that are audited by a public accountant or the Government Financial Supervisory Agency must be prepared in a long form (long reform report) and witness the reconciliation of commercial and fiscal profit and loss for taxpayers who are required to submit Annual SPT Accountants' opinion on financial statements which is audited by a Public Accountant signed by a Public Accountant who is not currently in the development of a Public Accountant Supervision Government Institution. Indicators of taxpayer compliance according to Suyono, NA (2016) cited by Nurhidayah $(2015 ; 22)$ are as follows:

1. Compliance to register Taxpayers who have fulfilled subjective and objective requirements are required to register at the Tax Office whose working area consists of the residence and place of business of the Taxpayer to obtain a Taxpayer Identification Number (NPWP).

2. Compliance in calculating and paying taxes payable. The calculated tax is then deposited into the state treasury through a bank or post office using a Tax Payment Form (SSP).

3. Compliance with the payment of tax arrears. Tax arrears are payable tax that has not been paid by the taxpayer after the due date of the imposition of the fine.

4. Compliance for depositing tax returns (SPT) Taxpayers are required to complete and submit their SPT to Tax Service Office by a deadline Submission of periodic tax returns no later than 20 days after the end of the tax period.

\section{Taxpayer's Knowledge of Compliance with Applicable Tax Regulations}

Individual taxpayers (WPOP), most of whom have a fairly high education, but have less knowledge of taxation. Taxpayer compliance is thought to be influenced by other factors such as the existence of strict tax sanctions, the complexity of tax regulations, the amount of assistance made by the finance department / tax consultant / account representative, which can facilitate tax compliance without having to study taxation. However, from the student's point of view it is contradictory because:

1) The field of accounting and taxation as a unit that must be understood by students;

2) Tax study is compulsory because it is a compulsory subject for study programs;

3) Students consider studying tax important when they enter the world of work;

4) Students consider the tax sanctions heavy enough so that they try to become compliant taxpayers;

5) Tax knowledge can be obtained from various sources such as radio, television, tax magazines, newspapers, internet, tax books (Supriyati, 2009).

Based on research conducted by Kemal Pambudi, Nessia Permana, and Tatang Ary in the Tax Service Office X Jember environment by comparing tax revenue and the number of NPWP holders in the six month period before and after the enactment of Law Number 36 Year 2008. The results of this study show that after the enactment of the law, tax revenue has decreased but the number of NPWP holders has increased (Khemal Pambudi R., Nessia Permana L., Tatang Ary Gumanti, 2009).

\section{Motivation Against Taxpayer Compliance in Paying Local Taxes}

Compliance is behavior to carry out or not carry out certain activities in accordance with applicable rules and regulations. Taxpayer compliance is the behavior of taxpayers in fulfilling their tax obligations in accordance with applicable regulations. Individual or group behavior is strongly influenced by motivation. Motivation is a drive that can generate and direct behavior. The amount of motivation will affect the intensity of the behavior (motivated, without motivation, and apathetic) and the suitability of the behavioral goals (effective, ineffective). The influence of motivation on theoretical behavior can be discussed through the study of structure (content theory) and study of the process (process theory). Content theory focuses on the factors inherent in an individual that can cause, direct, maintain, and stop behavior. Process theory, explains and analyzes how behavior is raised, directed, maintained and stopped.

From the discussion of content theory, taxpayer compliance is closely related to the interests or needs that must be met, the need for taxpayers is to calculate the appropriate amount of tax. Appropriate tax is the amount of tax that does not legally violate tax regulations and is not economically burdensome for taxpayers. From the satisfaction process theory, obedient behavior in paying taxes can be encouraged by creating regulations that can accommodate and dynamize; sanctions and insertion (reinforcement theory), expectations (expectancy theory), a sense of justice (equty theory), and goals (goal setting theory) related to tax policy (Article, 2008).

\section{RESEARCH METHODOLOGY}

This research is a quantitative causality study that will examine the effect of the independent variable on the dependent variable. This study uses primary data collected by distributing questionnaires to respondents. The questionnaire was delivered directly to respondents who were taxpayers of city X, namely advertising companies in city X.

There are several variables to be examined in this study that can be identified and measured. The first variable is motivation. Motivation is an impulse that can direct behavior. The amount of motivation will affect the intensity of the behavior (motivated, without motivation, apathy) and also the suitability of the behavioral goals. In this study, it is oriented to the influence of motivation in carrying out regional tax compliance. The motivation variable is measured by the taxpayers' perceptions of various statements of motivation to pay taxes which motivate the taxpayers to comply with local taxation regulations. This perception measurement uses a Likert scale.

The second variable is knowledge of taxation, which is how much knowledge or insight into taxes the taxpayer has. Tax knowledge measures the perception of taxpayers related to knowledge of tax rates, obligations and rights, applicable tax regulations, tax sanctions, and calculation and reporting of taxes. 
The third variable is tax compliance which is defined as a condition in which the taxpayer fulfills all tax obligations and rights. The measurement of this variable, the taxpayer's perception, is related to the taxpayer compliance criteria. This dependent variable will be measured by a Likert scale. The population and sample that became the respondents in this study were advertisement companies in $\mathrm{X}$ which were taxpayers of the city of $\mathrm{X}$. The data collection technique was carried out by giving a questionnaire to 25 advertisement companies in X city. saturated (full sampling) (Scribd. Population and Sample).

Data collection was carried out by giving questionnaires to respondents directly and indirectly. Direct giving of questionnaires is done by visiting and giving the questionnaire directly to the respondent. Giving questionnaires indirectly is done by sending the questionnaire via email and facsimail to the respondent, which then the respondent will send back if the questionnaire has been filled in by the respondent.

Table 1. Questionnaire Statement

\begin{tabular}{l} 
Tax Knowledge \\
\hline - I know the function of the taxes I pay \\
- I know that paying taxes is the duty of every citizen \\
- I always follow the changes in tax regulations that apply \\
- I understand how to calculate the taxes I have to pay \\
- Taxes that I pay are in accordance with applicable regulations \\
- If I don't pay taxes, I will be penalized \\
Motivation to Pay Taxes \\
- Paying taxes is a citizen's obligation \\
- By paying taxes I am helping my local grow \\
- By paying taxes I contribute to the welfare of the surrounding area \\
- I committed an unlawful (criminal) act if I didn't pay taxes \\
- By paying taxes, the company's good reputation will be maintained \\
- The ease of administration provided by the Director General of Taxes to taxpayers makes it easier for \\
me to pay taxes \\
Taxpayer Compliance \\
- I am never late in paying taxes \\
- I have never experienced the license revocation of an advertisement that I installed \\
- I do bookkeeping in accordance with tax regulations \\
\end{tabular}

Data analysis technique is to use multiple regression method, because in this study examines the relationship between two independent variables $(\mathrm{X})$ on the dependent variable (Y). The two independent variables are motivation and knowledge of taxation, while the dependent variable is tax compliance (Eko Mulyadi, 2012).

\section{Validity test}

The validity test was carried out using Pearson's correlation of the 15 questionnaire statements given (Iwan Sri Wiwoho Mudjanarko, 2012). The results obtained are that from the 15 questionnaire statements given, there are two invalid statements, so the two statements are eliminated.

\section{RESULTS AND DISCUSSION}

\section{Result}

This study uses statistical software SPSS 17.0 as a tool for calculate / test the data obtained. The results of the calculation / testing data done are as follows:

Table 2. SPSS multiple regression calculation summary model

\begin{tabular}{|r|r|r|r|r|}
\hline Model & R & R Square & $\begin{array}{c}\text { Adjusted R } \\
\text { Square }\end{array}$ & $\begin{array}{c}\text { Std. Error of } \\
\text { the Estimate }\end{array}$ \\
\hline 1 & $.764^{2}$ & .656 & .550 & 1.70832 \\
\hline
\end{tabular}

a. Predictors: (Constant), knowledge, motivation

This section describes the degree of closeness of the relationship between variables.

- The $\mathrm{R}$ value of $0.764 \alpha$ indicates that the correlation / relationship between compliance with the two independent variables is strong (because the magnitude is> 0.5 ).

- The number of R Square or the coefficient of determination is 0.656 . This means that 0.656 or $65.6 \%$ of the variation in compliance can be explained by the variation of the two independent variables, namely knowledge and motivation. While the rest $(100-65.6=34.4)$ or $34.4 \%$ are explained by other causes. 
Table 3. SPSS multiple regression calculation table

\begin{tabular}{|r|r|r|r|r|r|}
\hline \multicolumn{1}{|c|}{ Model } & Sum of Square & Df & Mean Square & F & Sig. \\
\hline $1 \quad$ Regression & 81.041 & 2 & 47.521 & 19.544 & $.000^{\mathrm{a}}$ \\
Residual & 49.659 & 27 & 3.580 & & \\
Total & 150.700 & 29 & & & \\
\hline
\end{tabular}

a. Predictors: (Constant), knowledge, motivation

b. Dependent Variable: compliance

This section describes the levels of significance. From the ANOVA or F-test, the F-count was 19,544 with a significance level of 0,000 . Because this probability (level of significance) is smaller than 0.05 , this regression model can be used to predict the level of compliance of local taxpayers. In other words, the level of motivation and knowledge of taxpayers together affects the level of compliance.

Table 4. SPSS multiple regression calculations

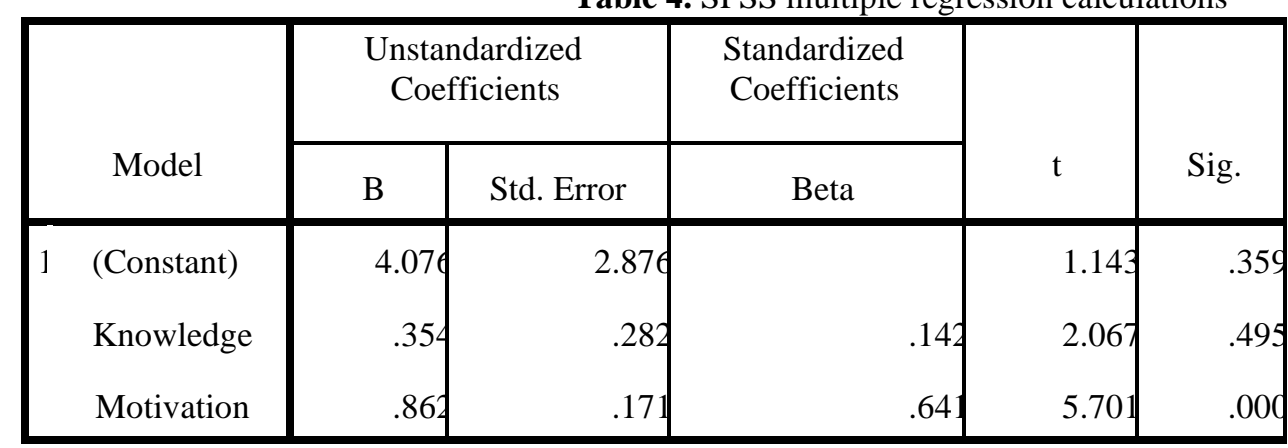

a. Dependent Variable: compliance

Table 4 illustrates how big the regression coefficient is. The regression equation obtained from the table is as follows: Compliance $=4.076+0.354$ Motivation +0.862 Knowledge. The t-test was used to test the significance of the constants and each independent variable. From the t-test, it can be used to build a hypothesis from the regression calculation. The hypothesis that is built is as follows:

Ho = insignificant regression coefficient

$\mathrm{Hi}=$ Significant Regression Coefficient

Decision making (based on probability, see column Sig.) Is as follows:

If Sig. $>0.05$ then Ho is accepted

If Sig. $<0.05$ then Ho is rejected, Hi is accepted

It can be seen that the Sig. for the three variables, namely constant $=0.359$, Knowledge $=0.495$ has a significance value $>$ 0.05 , thus Ho is accepted. Motivation produces a significance number $=0.000$ which is $>0.05$, thus Hi is accepted. These data show that the motivation variable does not affect the compliance of local taxpayers, while the knowledge variable is significant in influencing the compliance of local taxpayers.

\section{Discussion}

The results of statistical tests for knowledge show that knowledge is significant in influencing the compliance of local taxpayers. This fact is supported by the knowledge of taxpayers in calculating the advertisement tax rates that must be paid. So that local taxpayers do not feel disadvantaged when paying the taxes they bear. Another fact is that local taxpayers who follow any changes to the applicable tax laws make them more obedient because they know what consequences will be received if they do not implement the applicable regulations.

The results of statistical testing in this study indicate that motivation does not affect local taxpayer compliance. This fact is supported by the perception that paying local taxes is the duty of every citizen. Agreeing or not paying taxes is a must / compulsion for every citizen. This shows that the compliance of regional taxpayers is formed due to coercion, strict regulations, tax sanctions, and is not a desire / awareness of the regional taxpayers themselves. In addition, the thing that causes motivation does not affect the compliance of local taxpayers is because the advertisement tax uses an official assessment system, so that it is the tax authorities (tax officials) who play an active role in calculating the tax payable.

\section{CONCLUSIONS AND SUGGESTIONS}

\section{Conclusion}

This research is a quantitative research that measures the influence of motivation and knowledge of taxpayers on local taxpayer compliance. Respondents of this study were 25 rekalme companies located at X. 
The results of the multiple regression statistical test in this study produce the following conclusions: (1) The motivation of the taxpayer does not affect the compliance of local taxpayers in carrying out their tax obligations. This is supported by the perception that paying taxes is compulsion not a desire from within the regional taxpayer itself; (2) The use of the official assessment system in the advertisement tax collection also results in the motivation not to affect the compliance of local taxpayers in paying their taxes; (3) Knowledge of taxpayers that have a significant effect on regional taxpayer compliance. This is supported by the ability of taxpayers to calculate the amount of tax borne, so that local taxpayers do not feel disadvantaged.

\section{Suggestions}

Based on the conclusions outlined above, the following will describe some of the implications that are considered relevant to the research:

\section{For Tax Service Office}

The Tax Service Office always strives to improve the quality of tax services provided to taxpayers so that taxpayers feel satisfied and comfortable with those provided by tax officials. With the increase in the quality of tax services, the motivation of taxpayers to pay taxes will increase. Therefore, the quality of tax services provided by tax officials greatly affects the motivation of taxpayers to pay taxes.

2. For the government

This research is expected to be an input for the government in the legal aspects and simplification of tax laws and regulations. This is intended so that taxpayers are not difficult to understand taxation rules. In addition, strict and fair law enforcement for taxpayers who are negligent in paying taxes is needed so that it is hoped that the motivation of taxpayers to pay taxes will increase.

3. For Academics / Researchers

This research also has an impact on future researchers who want to carry out similar research as the authors did. Further research is expected to increase the number of research samples and expand the research sample area, not only taking samples at one Tax Service Office but several Tax Service Offices, so the research results are obtained with a higher level of generalization.

\section{REFERENCES}

Andinata, M. C. (2016). Analysis of the factors that affect individual taxpayer compliance in paying taxes. CALYPTRA, 4 (2), 115 .

Danarsi, S. N., \& Subroto, H. (2017). Factors Affecting Taxpayer Compliance In Paying Car Tax With Progressive Tax In The City Of Surakarta. Journal of Accounting and Tax, 18 (01).

Fikriningrum, W. K., \& Syafruddin, M. (2012). Analysis of factors affecting individual taxpayers in fulfilling their tax obligations (case study at the X Semarang Candisari tax service office). Doctoral dissertation. Faculty of Economics and Business.

Fuadi, A. O., \& Mangoting, Y. (2013). The influence of tax officer service quality, tax sanctions and tax compliance costs on MSME taxpayer compliance. Tax \& Accounting Review, 1 (1), 18.

GHONI, H. A. A. (2012). The influence of motivation and knowledge of taxpayers on local taxpayer compliance. AKUNESA Accounting Journal, 1 (1).

Hardiningsih, P., \& Yulianawati, N. (2011). Factors affecting WTP. Dynamics of Finance and Banking, 3 (1), $126-142$.

Ketut, A. R. S. P. I. (2013). Factors affecting taxpayer compliance in paying motor vehicle tax in Denpasar. E-Journal of Accounting, 2 (3), 661-677.

Listyowati, Y. C. S. (2018). Factors Affecting Taxpayer Compliance in Paying Taxes. Journal of Accounting and Business Research Airlangga, 3 (1).

Soegiarto, C. (2014). Factors that affect the willingness to pay taxes for individual taxpayers who do independent work at X Centers. Doctoral dissertation. Widya Mandala Catholic University X..

Suyanto, S., \& Putri, I. S. (2017). The Influence of Taxpayers' Perceptions of Tax Amnesty Policy (Tax Amnesty), and Motivation to Pay Taxes on Tax Compliance. Journal of Accounting, 5 (1), 49-56.

Suyono, N. A. (2016). Factors that influence tax compliance at the Wonosobo Tax Office. Journal of Research and Community Service UNSIQ, 3 (1), 1-10.

Trisnawati, M., \& Sudirman, W. (2015). Analysis of Factors Affecting Taxpayer Compliance Paying Hotel Tax, Restaurant Tax and Entertainment Tax in Denpasar City. E-Journal of Economics and Business, Udayana University, 4 (12), $975-1000$.

Hasibuan M.S.P. 2005. Organization and Motivation: Basis for Increasing Productivity, Bumi Aksara: Jakarta.

Kapuk Online, 2011, Basic Human Needs, accessed July 3, 2012, Minister of Finance Decree No.554 / KMK.04 / 2000 j.o KMK No.235 / KMK.03 / 2003 concerning Determination of Compliant Taxpayers.

Mardiasmo. 2006. Taxation. Andi Offset: Yogyakarta.

Pambudi R. Khemal, Nessia Permana L., Tatang Ary Gumanti. 2009. The Impact of Law Number 36 Year 2008 Concerning Income Taxes on Tax Sector Revenues: A Case Study at KPP Pratama Jember

Supriyati and Nur Hidayati, 2007, "The Influence of Tax Knowledge and Taxpayer Perceptions of Taxpayer Compliance". Journal of Accounting and Information Technology, Vol. 7, No. 1, pp. 41-50.

X Post Online, 2011, 40 Reklame Besar Masuk Daftar Bongkar Paksa, diakses $30 \quad$ Juni 2012,

X Post Online, 2012, Pajak Reklame dan PBB Jeblok, diakses 30 juni 2012,

Taxation, 2009, Sistem Perpajakan di Indonesia, diakses 14 Agustus 2012,

Undang-Undang Nomor 16 Tahun 2000 Tentang Ketentuan Umum dan Tata Cara Perpajakan. 